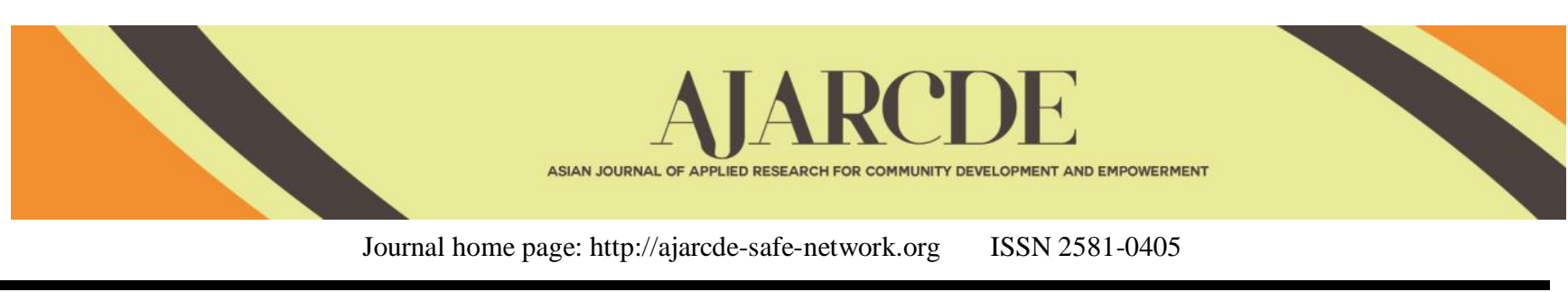

\title{
Hierarchy of Needs to Staff Performances that Affect to Employees Loyalty of Chengde Steel Logistics Co.,Ltd.
}

\author{
Jiajun Liu and Prapatsorn Kittimanorom ${ }^{1}$ \\ 1. Master of Business Administration, Rajapruk University. Thailand \\ *Corresponding author: poopleponpae@gmail.com
}

\section{ARTICLE INFO}

Article History:

Received: July 3, 2019

Final Revision: November 12, 2019

Available Online: December 11, 2019

\section{KEYWORDS}

The Hierarchy of needs, Performance, Employees Loyalty.

\section{CORRESPONDING AUTHOR}

*E-mail: poopleponpae@ gmail.com

\section{A B S T R A C T}

The objective of this study was to investigate the hierarchy of needs to staff performances, to study employees' loyalty of Chengde Steel Logistics Co., Ltd., and to study the relationship of the hierarchy of needs to staff performances that employees Loyalty of Chengde Steel Logistics Co., Ltd. The research instrument was the questionnaire. Data collected were analyzed through frequency, percentage, mean, standard deviation and Pearson's correlation coefficient. The sampling of this study was 223 individuals, those aged between 21-30 years, graduated with a bachelor's degree, 31-40 years of the work period, and those with production staff. The analytic results of the hierarchy of needs to staff performances of Chengde Steel Logistics Co., Ltd, with mean score of 4.18 from highest to lowest mean scores as follows, the respondents had high, ate level, needs for Physiological, needs for Security or Safety needs, and need for esteem needs at low level respectively. In terms of Loyalty, overall the respondents had a moderate level, with a mean score of 3.42. The factors were ranked from highest to lowest mean scores as follows: affective aspect, behavioral aspect and cognitive aspect at low level respectively. The results of hypothesis testing showed that the Hierarchy of needs to staff performances positively related to the employee's loyalty to Chengde Steel Logistics Co., Ltd, was high related. The statistic significant was .05

\section{INTRODUCTION}

The importance of human resource elements in the overall input cost of enterprises is increasing day by day. How to manage employees through compensation management is more important. Salary satisfaction of enterprise employees is a key factor that affects the realization of enterprise goals and an important content of modern enterprise human resource management. It is the need of enterprise development strategy to improve employees' salary satisfaction. Human capital is the key to organizational effectiveness, and an organization's most valuable asset is its employees. Employee retention is critical to the productivity and competitiveness of any organization. Retaining skilled and well-equipped employees in an organization is closely related to the development of the company and the overall performance of the organization. Satisfied employees will definitely contribute to the organization's goals and its competitive advantage over competitors. There is a significant correlation between salary management and employee job satisfaction, which has a certain impact on employee motivation and job satisfaction. That Compensation is something accepted to employees, whether in form financial or non-financial a reward for employee's contribution to organization. Management of compensation is a very important activity to make employees quite satisfied in their work. Compensation can acquire or create and maintain productivity. Without adequate compensation, existing employees tend to leave the organization and organizations will have difficulty in replacement. Especially in recruiting. Compensation is everything received by employees as a reward for its contribution to company or organization. Compensation is everything that employees receive as a reward for their work. Compensation as rewards and can be defined as any form of reward given to employees for contributions they provide to organization Generally, purpose of compensation management is to assist companies to achieve the strategic objectives of corporate success and ensuring internal justice and external justice. External justice ensures that jobs are fairly compensated based on compatible work in labor market. The internal justice ensures that demand for higher positions and more qualified persons within company will be given higher payouts.

Therefore, the researcher an interested is studying focuses on the hierarchy of needs to staff performances that affect to employees loyalty of chengde steel logistics co., ltd. is an important aspect of salary strategy: in particular, staff performances that affect to employees loyalty management is capable of solving the 'problem of strategic fit'. and employee job satisfaction, as elements of a dualistic model which provides answers to the question of how to create strategic fit. It also explains why a strong employee job satisfaction is often 
associated with compensation management success. An also suggests a specific way to operationalize employee jobs satisfaction.

\section{MATERIALS AND METHODS}

\subsection{Population and sample}

In this study, Chengde Steel Logistics Co., Ltd. Selected as the target group. The company is a typical online manufacturing industry. It also faces typical development issues. It is fully in line with the subject of the study. The company has a total of 500 employees and managers. The researchers used the sample scales of [1]. The table shows that for 500 groups, the sample size is 223 Samples.

\subsection{Research Instrument}

This study used a questionnaire survey method to investigate There is a relationship between hierarchy of needs to staff performances that affect to employees loyalty of Chengde Steel Logistics Co., Ltd. The questionnaire design is divided into fourth parts. The first part is the demographics of the employees. The design of the problem is closed and has a choice of answers. The second part is the staff performances level. The third part of the Employee loyalty level. The fourth part is the relationship between hierarchy of needs to staff performances that affect to employees loyalty of Chengde Steel Logistics Co., Ltd. The questionnaire is divided into two areas: individual staff performance and employee loyalty are designed as Level 5 answers [2]. 1 = very disagree, 2 = disagree, $3=$ neutral, $4=$ agree, $5=$ strongly agree, all questions in the questionnaire will be fixed after the professional has conducted a reliability effectiveness test. This process ensures that all issues are valid and reliable.

\subsection{Data Analysis}

Descriptive statistical analysis was used to describe the level of hierarchy of needs to staff performances and employee's loyalty. These data are described by frequency, percentage, average and standard deviation. The relationship between hierarchy of needs to staff performances that affect to employees loyalty of chengde steel logistics co., ltd. was use Pearson Product - Moment Correlation Coefficient

\section{RESULT AND DISCUSSION}

\subsection{The Opinion of Staff Performances}

Table 1. Mean and Std. Deviation of Staff Performance of Chengde Steel Logistics Co., Ltd.

\begin{tabular}{|l|c|l|l|l|}
\hline $\begin{array}{l}\text { The Opinion of Staff } \\
\text { performances } \\
\text { (Overall) }\end{array}$ & $\overline{\mathbf{X}}$ & SD & Level & Rank \\
\hline 1.Physiological & 4.20 & 0.19 & Agree & 1 \\
\hline 2.Safety & 3.69 & 0.96 & Agree & 3 \\
\hline $\begin{array}{l}\text { 3.Love and } \\
\text { belongingness }\end{array}$ & 4.18 & 0.23 & Agree & 2 \\
\hline 4.Esteem & 3.07 & 0.93 & Neutral & 5 \\
\hline 5.Self-actualization & 3.26 & 0.82 & Neutral & 4 \\
\hline \multicolumn{1}{|c|}{ Total } & $\mathbf{4 . 1 8}$ & $\mathbf{0 . 2 3}$ & Agree & \\
\hline \multicolumn{2}{|l|}{} \\
\hline
\end{tabular}

Table 1 the overall was found that, the respondents gave importance to level of staff performance was at agree $\left(\mathrm{X}^{-}=4.18\right.$, $\mathrm{SD}=0.23)$, rank first leasers was physiological was at agree $\left(\mathrm{X}^{-}\right.$ $=4.20, \mathrm{SD}=0.19)$, rank second leasers was Love and belongingness was at agree $\left(\mathrm{X}^{-}=4.18, \mathrm{SD}=0.23\right)$, the lowest rank leasers was esteem was at neutral $\left(\mathrm{X}^{-}=3.07, \mathrm{SD}=0.93\right)$.

\subsection{The Opinion of Employee Loyalty}

Table 2. Mean and Std. Deviation of Employee Loyalty of Chengde Steel Logistics Co., Ltd. (Overall)

\begin{tabular}{|c|c|c|c|c|}
\hline $\begin{array}{c}\text { The Opinion of } \\
\text { Employee loyalty } \\
\text { (Overall) }\end{array}$ & $\overline{\mathbf{X}}$ & SD & Level & Rank \\
\hline $\begin{array}{l}\text { 1. Behavioral } \\
\text { aspect }\end{array}$ & 3.34 & 0.85 & Neutral & 2 \\
\hline 2. Affective aspect & 3.49 & 1.26 & $\begin{array}{c}\text { Strongly } \\
\text { agree }\end{array}$ & 1 \\
\hline 3. Cognitive aspect & 3.33 & 0.83 & Neutral & 3 \\
\hline Total & 3.42 & 0.98 & Agree & \\
\hline
\end{tabular}

Table 2 the overall was found that, the respondents gave importance to level of employee loyalty was at agree $\left(\mathrm{X}^{-}=3.42\right.$, $\mathrm{SD}=0.98)$, rank first leasers was affective aspect was at strongly agree $\left(\mathrm{X}^{-}=3.49, \mathrm{SD}=1.26\right)$, rank second leasers was behavioral aspect was at neutral $\left(\mathrm{X}^{-}=3.34, \mathrm{SD}=0.85\right)$, the lowest rank leasers was cognitive aspect was at neutral $\left(\mathrm{X}^{-}=3.33, \mathrm{SD}=0.98\right)$.

\subsection{Hypothesis test results}

Table 3. The Relationship Between Hierarchy of needs to Staff Performances that affect to Employees Loyalty of Chengde Steel Logistics Co., Ltd. (Overall)

\begin{tabular}{|c|c|c|c|}
\hline \multirow{4}{*}{$\begin{array}{c}\text { Staff } \\
\text { Performance }\end{array}$} & \multicolumn{3}{|c|}{ Employee Loyalty } \\
\hline & $\begin{array}{c}\text { Behavioral } \\
\text { Aspect }\end{array}$ & $\begin{array}{l}\text { Affective } \\
\text { Aspect }\end{array}$ & $\begin{array}{l}\text { Cognitive } \\
\text { aspect }\end{array}$ \\
\hline & $\begin{array}{l}\text { Sig.(2- } \\
\text { tailed) }\end{array}$ & $\begin{array}{l}\text { Sig.(2- } \\
\text { tailed) }\end{array}$ & $\begin{array}{l}\text { Sig.(2- } \\
\text { tailed) }\end{array}$ \\
\hline & $\begin{array}{c}\text { Strong } \\
\text { positive } \\
\text { relationship }\end{array}$ & $\begin{array}{c}\text { Strong } \\
\text { positive } \\
\text { relationship }\end{array}$ & $\begin{array}{c}\text { Strong } \\
\text { positive } \\
\text { relationship }\end{array}$ \\
\hline Physiological & .72 & .57 & .58 \\
\hline Safety & .54 & .62 & .56 \\
\hline $\begin{array}{c}\text { Love and } \\
\text { Belongingness }\end{array}$ & .71 & .56 & .77 \\
\hline Esteem & .70 & .69 & .78 \\
\hline $\begin{array}{c}\text { Self- } \\
\text { Actualization }\end{array}$ & .62 & .52 & .79 \\
\hline Total & .70 & .56 & .78 \\
\hline
\end{tabular}

**. Correlation is significant at the 0.01 level (2-tailed).

Table 3 shows that the hierarchy of needs to staff performances of Chengde Steel Logistics Co., Ltd., was positively related to employees loyalty was positive correlation between staff performance and cognitive aspect was at strong $(r=0.78)$, Describes the correlation analysis of hierarchy of needs to staff performances that affect to employees loyalty of Chengde Steel Logistics Co., Ltd., show the correlation all the variables including behavioral aspect was at strong $(r=0.70)$, the lowest rank leaders were affective aspect was at moderate $(r=.56)$ respectively.

https://doi.org/10.29165/ajarcde.v3i1.25 


\subsection{Discussions}

Found that, the motivation to work is associated with loyalty to the organization's staff. Chengde Steel Logistics Co., Ltd. demand side of the body showed a fund or fund for the employees. A health insurance reimbursement for treating illness to employees. Uniformed employees have a positive image of the organization. The security requirements that need safety or security work. Needs to be protected lives and property. To protect protection warmth and social needs that, when you are done. You feel proud He was introduced to the works of talks in academic work or be appreciated. And coexistence and acceptance of others. The demand for credit has shown that selfesteem. The independence and freedom to have a respectable reputation, praised veneration. With distinction Have confidence in yourself Ability and success. Need a good sense from my colleagues. To find success, the demand for pride. To make things better or more efficient at moderate levels. To be a leader in deciding Influences others by working effectively to solve problems or work more complicated. Consistent with research's [3], that many factors can determine the quality of working life. One of which is the environment in the workplace. The staff has been very significant impact on the organization. As an result of changes in the work environment. Consistent with research [4], said the quality of working life is generally associated with the concrete of the organization, which will allow the organization to recognize that they are safe, satisfied and chance. the growth and further development as an individual. The quality of working life Get more attention in the world as well as in modern society, who spend more than a third of their lives at work. Therefore, the importance and significance of the quality of work life. The unrivaled Quality of work life Health, safety and security in employment, satisfaction with work stress, work environment, work-life balance work and relationships in human [5], that intention and desire are determined to maintain their memberships continue to work towards achieving the goals of the organization. The resign whether organizations are in a normal state or in a crisis.

\subsection{Suggestions}

The results of this study indicate the motivation to act with loyalty to the organization and what is relevant. The study is suggested to be useful to use as a guideline to improve staff Chengde Steel Logistics Co., Ltd. are loyal to the organization, the greater

1. Consider promoted staff. And make the decisions that have been assigned. Participate in the evaluation of performance. So that employees feel that. Gain the trust of their superiors. The assignments are important to the organization that has been recognized by other people and valuable in society and feel good with my colleagues. Employees are confident in themselves. And are keen to develop themselves in order to succeed.

2. The management company should provide employees the opportunity to work on challenging and complex content to live in a situation that is highly competitive. Inspiring a responsible job. Leadership decisions and influence over others by working effectively.

3. Companies should clearly assess performance and fairness. Opportunity to have a continuous progress and stability. And success in life Salary and Compensation Other benefits Reasonable and fair, companies should be encouraged to develop to seek a breakthrough in the channel and promoted by routing progression in a career (Career path) a clear and informed throughout the organization. written as Mention awards to employees whose work is manifested.

4. Encourage fund or fund for the employees. A health insurance reimbursement for treating illness to employees. There is a place for exercise. The dining room Relax and read a book for employees.

\section{CONCLUSION}

In terms of Loyalty, overall the respondents had moderate level, with mean score of 3.42. The factors were ranked from highest to lowest mean scores as follows: affective aspect, behavioral aspect and cognitive aspect at low level respectively. The results of hypothesis testing showed that the Hierarchy of needs to staff performances positively related to the employees loyalty of Chengde Steel Logistics Co., Ltd, was high related. The statistic significant was .05

\section{ACKNOWLEDGMENT}

I want to thanks those who contributed and helped make this research possible. First of all, I would like to express my heartfelt thanks to Dr.Prapatsorn Kittimanorom for her valuable advice, encouragement and help in completing this research project, as well as her love for education. In addition, I am grateful for Assoc. Prof. Sasanant Vivadhnajat MBA Director, Rajapruk University and others person for suggestions and all their help, Dr.Yootanart Boonyachai.

\section{REFERENCE}

[1]. Krejcie, R. V. \& Morgan, D. W. (1970). Determining Sample Size for Research Activities. Educational and Psychological Measurement, 30(3), pp. 607-610..

[2]. Likert, R. (1932). A technique for the measurement of attitudes. Archives of Psychology, 1-55. Referred in Warmbrod, J.R. (2014). Reporting and Interpreting Scores.

[3]. Rethinam, Guna Seelan and Ismail, Maimunah (2007). The quality of work life, the perspective of information and technology experts. Richand

[4]. Shoeb Ahmad (2013). Quality of work life. University of Hail - Management and information System.

[5]. Steers (1991) Introduction to Organization Behavior. New York: Harper Collin Publishers. 